Published in "Tourism review", 2020, vol. 75, no 1, pp. 310-313, which should be cited to refer to this work.

DOI: 10.1108/TR-04-2019-0127

\title{
Reputation in travel and tourism: a perspective article
}

\author{
Alessandro Inversini \\ Ecole hôtelière de Lausanne \\ HES-SO University of Applied Sciences and Arts Western Switzerland. \\ Route de Cojonnex 18 -1000 Lausanne 25 (Switzerland) \\ alessandro.inversini@ehl.ch \\ +41217851085
}

\section{Introduction}

The purpose of this contribution is to shed light on the concept of brand reputation with a focus on the travel and tourism domain. Additionally, the article will contribute to the discussion of future perspectives and developments of this concept. To generate a better understanding about brand reputation, it is important to pinpoint the key dimensions related to the concept of 'brand'. The debate about the multifaceted notion of brand traces back to the early sixties (with the seminal work of Jung,1964). If brand identity can be understood as a managerial issue (Walker, 2010), brand image can be understood as the consumer's interpretation of brand identity (Kapferer, 2008). Different stakeholders can have different perceptions of the same brand (Dowling, 1986); therefore different brand images may exists simultaneously (Argenti \& Druckenmiller, 2004). This led to the conceptualization of 'brand reputation', which can generally be understood as the cumulative sum of the different brand image perceptions of different stakeholders over time (Walker, 2010).

\section{Past Perspectives on Reputation}

Organizations should care about reputation because having a good reputation can ensure sustainable competitive advantage (e.g. Fombrun, 1996; Hall, 1993; Roberts \& Dowling, 2002). This can be achieved by lowering firm promotional costs (e.g. Deephouse, 2000), enabling firms to charge premium prices (e.g. Fombrun \& Shanley, 1990), attracting investors (e.g. Srivastava, Mclnish, Wood, \& Capraro, 1997) and customers (e.g. Fombrun, 1996), increasing profitability (e.g. Roberts \& Dowling, 2002), and creating competitive barriers (Milgrom \& Roberts, 1982). Reputation is a very complex construct that is difficult to define (Barnett, Jermier, \& Lafferty, 2006). To date, few published papers include a proper definition of what reputation is. According to Walker (2010), there are five key attributes to consider when defining reputation: (i) reputation is based on perceptions; (ii) it is the aggregate perception of all stakeholders; and (iii) it is comparative (Wartick, 2002). Two additional attributes are often mentioned in the literature (Walker, 2010): reputation can be (iv) positive or negative, and (v) stable and enduring. Together, these five attributes can lead to a comprehensive definition of reputation that reflects leading articles in the scholarly literature. Reputation can be considered as an asset that evolves over time and requires investment to create and maintain. As an asset, reputation needs to be developed, managed, and protected in an increasingly volatile environment (Mailath \& Samuelson, 2001).

The disruptive rise of the internet and the consequent growth of social media challenged and revolutionized the company-consumer relationship. Marketing communications paradigms shifted from the traditional 'one-to-many' to the interactive 'many-to-many' where audiences 
participate in content creation over the medium (Hoffman \& Novak, 1996). Interactivity impacted global branding strategies (Hoffman, 2000), giving a new collaborative dimension to brand reputation (Buhalis \& Inversini, 2014). Before the advent of the internet and social media, brand reputation was measured with stakeholder surveys (e.g. Fombrun, 1996). Nowadays, due to the rise of user generated content (e.g. reviews), reputation can be understood and measured directly through social media by harvesting online opinions about a good or a service (Inversini, Marchiori, Dedekind, \& Cantoni, 2010). Online reputation becomes a critical issue for firms around the world, including destinations and hospitality establishments (Inversini, Cantoni, \& Buhalis, 2009). In hospitality, as stated by Anderson (2012), a 1 percent increase in a hotel's online reputation score leads up to a (i) 0.89 percent increase in average daily rate, a (ii) 0.54 percent increase in occupation, and a (iii) 1.42 percent increase in revenue per available room.

\section{Future Perspectives on Reputation}

As the development of digital media and digital technologies continues, consumer data points are increasing dramatically. Forbes stated that by 2020,1.7MB of data will be created every second for every person on earth (Marr, 2018). This enormous amount of data, indicating consumer behavior during the customer's journey (Inversini, 2017), along with written and unwritten (but recorded) digital opinions, helps to shape the reputation of travel brands and firms. This now concerns not only the remembered perceptions (i.e. in the form of explicit travel reviews), but also actual and lived experiences and behaviors with the product/service. Organizations in travel have recognized the importance of reputation as a critical asset (Buhalis \& Inversini, 2014) and are increasingly incorporating stakeholders' perceptions in their product development (Reid, Marion, Hultink, \& Barczak, 2018). The study of online reputation is also becoming very sophisticated and can give real time indications of pricing, investments, and acquisitions toward building competitive barriers. Furthermore, with the growing datafication (Lycett, 2013) of the business world, online reputation is becoming not only a monitoring activity (i.e. providing descriptive information based on past customers' behavior) for travel firms, but a business intelligence activity which can generate prescriptive recommendations on (i) the (near) future orientation of the firm (Bedeley \& Nemati, 2014) and on real time services customization and co-creation (Buhalis \& Sinarta, 2019).

\section{Conclusions}

Reputation can be conceptualized as the cumulative sum of the different brand image perceptions of different stakeholders over time collected via different tools in different media. When reputation is managed properly, it can create competitive barriers. A proper understanding of reputation (and especially online reputation) is a critical success factor for companies, particularly in travel. Due to the increasing datafication of society (Lycett, 2013) and of the business world, (online) reputation is becoming the backbone of competitiveness towards the generation of prescriptive analytics. Reputation can now be studied and managed in real-time and not only 'ex-post' once a brand breakdown occurred. Given different customer data points and interactions, breakdowns can be avoided and/or converted into opportunities.

\section{References}

Anderson, C. (2012). The Impact of Social Media on Lodging Performance. Center for Hospitality Research Publications. Retrieved from https://scholarship.sha.cornell.edu/chrpubs/5 
Argenti, P. A., \& Druckenmiller, B. (2004). Reputation and the Corporate Brand. Corporate Reputation Review, 6(4), 368-374. https://doi.org/10.1057/palgrave.crr.1540005

Barnett, M. L., Jermier, J. M., \& Lafferty, B. A. (2006). Corporate Reputation: The Definitional Landscape. Corporate Reputation Review, 9(1), 26-38.

https://doi.org/10.1057/palgrave.crr.1550012

Bedeley, R., \& Nemati, H. (2014). Big Data Analytics: A Key Capability for Competitive Advantage. Presented at the 20th Americas Conference on Information Systems (AMCIS), Savannah, GA, 7-9 August.

Buhalis, D, \& Inversini, A. (2014). Tourism Branding and Reputation in the Age of Social Media. In Tourism Management, Marketing and Development: the Importance of Networks and ICTs (pp. 15-40). Palgrave, Macmillan.

Buhalis, Dimitrios, \& Sinarta, Y. (2019). Real-time co-creation and nowness service: lessons from tourism and hospitality. Journal of Travel \& Tourism Marketing, 36(5), 563-582. https://doi.org/10.1080/10548408.2019.1592059

Dowling, G. R. (1986). Managing your corporate images. Industrial Marketing Management, 15(2), 109-115. https://doi.org/10.1016/0019-8501(86)90051-9

Fombrun, C. J. (1996). Reputation: Realizing Value from the Corporate Image. Harvard Business School Publishing India Pvt. Limited.

Fombrun, C., \& Shanley, M. (1990). What's in a Name? Reputation Building and Corporate Strategy. Academy of Management Journal, 33(2), 233-258. https://doi.org/10.2307/256324

Hall, R. (1993). A framework linking intangible resources and capabilities to sustainable competitive advantage. Strategic Management Journal, 14(8), 607-618. https://doi.org/10.1002/smj.4250140804

Hoffman, D. L. (2000). The Revolution Will Not Be Televised: Introduction to the Special Issue on Marketing Science and the Internet. Marketing Science, 19(1), 1-3. https://doi.org/10.1287/mksc.19.1.1.15181

Hoffman, D. L., \& Novak, T. P. (1996). Marketing in hypermedia computer-mediated environments: Conceptual foundations. Journal of Marketing, 60(3), 50.

Inversini, A. (2017). Managing passengers' experience through mobile moments. Journal of Air Transport Management, 62, 78-81. https://doi.org/10.1016/j.jairtraman.2017.03.009

Inversini, A., Cantoni, L., \& Buhalis, D. (2009). Destinations' Information Competition and Web Reputation. Information Technology \& Tourism, 11(3), 221-234. https://doi.org/10.3727/109830509X12596187863991

Inversini, A., Marchiori, E., Dedekind, C., \& Cantoni, L. (2010). Applying a Conceptual Framework to Analyze Online Reputation of Tourism Destinations. In D. U. Gretzel, D. R. Law, \& P. M. Fuchs (Eds.), Information and Communication Technologies in Tourism 2010 (pp. 321-332). Retrieved from http://link.springer.com/chapter/10.1007/978-3-211-99407-8_27

Jung, C. (1964). Man and His Symbols. Dell Publishing.

Kapferer, J. N. (2008). The New Strategic Brand Management. London: Kogan Page.

Lycett, M. (2013). 'Datafication': making sense of (big) data in a complex world. European Journal of Information Systems, 22(4), 381-386. https://doi.org/10.1057/ejis.2013.10

Mailath, G. J., \& Samuelson, L. (2001). Who Wants a Good Reputation? The Review of Economic Studies, 68(2), 415-441. https://doi.org/10.1111/1467-937X.00175

Marr, B. (2018). How Much Data Do We Create Every Day? The Mind-Blowing Stats Everyone Should Read. Forbes. Retrieved from 
https://www.forbes.com/sites/bernardmarr/2018/05/21/how-much-data-do-we-createevery-day-the-mind-blowing-stats-everyone-should-read/\#1fb0854260ba

Milgrom, P., \& Roberts, J. (1982). Predation, reputation, and entry deterrence. Journal of Economic Theory, 27(2), 280-312. https://doi.org/10.1016/0022-0531(82)90031-X

Reid, M., Marion, T. J., Hultink, E. J., \& Barczak, G. (2018). Open Innovation, IT Orientation, and External Collaboration: Implications for the Use of New Media and Social Networking IT in New Product Development. In World Scientific Reference on Innovation (Vols. 1-4, pp. 37-76). https://doi.org/10.1142/9789813149083_0003

Roberts, P. W., \& Dowling, G. R. (2002). Corporate reputation and sustained superior financial performance. Strategic Management Journal, 23(12), 1077-1093. https://doi.org/10.1002/smj.274

Srivastava, R. K., Mclnish, T. H., Wood, R. A., \& Capraro, A. J. (1997). Part IV: How Do Reputations Affect Corporate Performance?: The Value of Corporate Reputation: Evidence from the Equity Markets. Corporate Reputation Review, 1(1), 61-68. https://doi.org/10.1057/palgrave.crr.1540018

Walker, K. (2010). A Systematic Review of the Corporate Reputation Literature: Definition, Measurement, and Theory. Corporate Reputation Review, 12(4), 357-387. https://doi.org/10.1057/crr.2009.26

Wartick, S. L. (2002). Measuring Corporate Reputation Definition and Data. Business \& Society, 41(4), 371-392. https://doi.org/10.1177/0007650302238774 